\author{
Đorđe N. Petrović \\ International Center for Orthodox Studies, Niš \\ e-mail: georgen.petrovich@gmail.com
}

\title{
THE HIGH-PRIESTLY MINISTRY OF CHRIST: AN INTRODUCTION TO SERGIUS BULGAKOV'S SACRAMENTAL THEOLOGY
}

\begin{abstract}
The high-priestly ministry of Christ is one of the themes explored by Bulgakov especially in his work the Lamb of God. The title suggests the main theme of high-priestly ministry of Christ as an introduction to Bulgakov's theology for two reasons. The first one is Christ's ministry is accomplished on the Cross and through the Resurrection. The second reason is Christ' ministry continued rather extended in the Eucharist. Regardless some theologoumenon which arguably categorizes Bulgakov as an orthodox thinker or philosopher rather than theologian, the theme of high-priest ministry discloses the core of his understanding of Christology and Sacramental theology. The challenge in this study is to recognize the highpriestly ministry of Christ in Bulgakov's theology as extended in the Eucharist. The goal is also to revalue few aspects of the term high-priest and its significance for theology at large.

Key words: High-priest, Christ' ministry, deification, Eucharist, Great Friday, Incarnation and Resurrection.

The Passion story as well as the meaning of the Great Friday has never been approached exclusively in the Orthodox Church. The glorious death of Christ is a path and one step closer to the ultimate purpose of His life on earth. It is a victory over sin and evil-life over death. The main argument of the high-priestly ministry of Christ "is manifested as Eucharistic power, the mysterious connection of the glorified Christ with the man in communion and the unceasing sanctification of the elements of the world through the presence in them of the Sacred Gifts, the Body and the Blood of Christ". 1 This view discloses the claim which brings the connection of the Great Friday and the Resurrection with the whole history of the life of Christ beginning with the Incarnation. In an attempt to support this claim, two monumental frescoes as indicated in the text body will serve the purpose to approach the mystery high-priestly ministry of Christ in Bulgakov's sacramental theology.
\end{abstract}

1 Bulgakov 2008, 436. 


\section{The Great Friday: a meaning of Christ's suffering and experience of death}

Pauline theology witnesses to Corinthians Christ who became poor ${ }^{2}$ that we may become rich (II Cor 8, 9). The "royal exchange"3 has been bridged by Christ. He descends from heaven, but how do we come to Christ and how is that whole theme situated within the Triduum for the sake of humanity? If we biblically examine the earthly life of Christ, we will soon realize that from the moment He took the human flesh until the event of the Resurrection, Christ had been humiliated and suffered. Suffering and death followed him from the moment Christ was born until the Crucifixion. The one who lived among sinners was without sin. Was not that a true sacrifice to begin with? He was not born to die for our sins so that He may redeem us, but to resurrect, so we may resurrect with Him also. Christ's ministry was not redemptive only which was a ground for reconciliation. His mission and sacrifice as a whole culminating on the Cross extend further. The purpose is to bring humanity to the communion with God. This is what the term deification primarily stands for. In this context, the meaning of the great Friday is a symbolic (where the term $\sigma v \mu \beta \alpha \dot{\alpha} \lambda \lambda \omega$ denotes primarily to put together or to connect) with the night before along with the Sunday morning. So, what is the symbolic meaning of Christ's sacrifice in the theological sense of the term sacrifice?

Bulgakov states that redemption establishes universal deification of man; the foundation for the true divine-human relationship and communion. Redemption is the way to deification. He uses the term deification ${ }^{4}$ as a popular terminology along with imago Dei of patristic literature. According to his thread of thoughts, we may mildly replace this term with en eschatological realm for humanity and begin with the Last Supper narrative (I Cor 11, 24) and Christ as exercising the high priestly ministry: "The first and fundamental testimony, common to all three Synoptics is the narrative of the Last Supper, in which the establishment of the Eucharist is portrayed with the features exclusively proper to the offering of sacrifice." 5 Pauline theology to take and eat Body of Christ (I Cor 11,24) as well as John's testimony "the bread that I will give is my flesh, which I will give for the life of the world" makes the foundation for the Orthodox faith. Christ is the sacrificed one and one who is sacrificing priest. It is Christ who was brought to the Father on Cross and it is Christ who is being offered on the holy table as well ("offering and offered, receiving and distributed..." as we read it in the Eucharistic prayer).

The Lamb of God, the same-titled book by Bulgakov, speaks of Christ as the sacrifice. Christ is that Lamb of God that John the Baptist speaks of with a loud voice. In fact, John perceived Christ from the beginning not as a fluffy animal as so widely spread in the Christian art, but as the Lamb of God which takes away the sin of the world (Jn 1, 29). He is the one who is being slained and who has redeemed us by His blood (Rev 5, 9). But, Christ offered His body

2 " $\mathrm{He}$, who is, becomes. The uncreated is created. He, whom no locality can hold, through the mediation of an intelligent soul, is contained within the limits of flesh. He who enriches others, Himself becomes poor, and because $\mathrm{He}$ assumed the poverty of our flesh, we are made rich with His divinity. Fullness empties itself, because He empties Himself of His glory for a time in order that I participate in His fullness". Also to say, as much as Christ is 'emptying' Himself until death on the Cross He remains transcendent and that is what is going to be seen and experienced"; The Theologian 2004, 544.

3 The Royal exchange formula precisely means an exchange of properties not the establishment of an identity of the essence. Christ became human so that humanity could become sons by adoption. Our sonship is confirmed by Christ through Baptism. The Royal Exchange is a common phrase by Irenaeus; Irenaeus 2004, 474.

4 The twenty years of research by Norman Russell is dedicated on theologumena of deification. He argues that the whole 'movement' of Imago Dei expresses and signifies other connotation then simply humanity becoming gods; Russell 2004.

5 Bulgakov 2008, 334. 
and blood mystically long before He did it physically. Synoptic Gospels do not coincide with the Johannine date of the Last supper for an obvious reason: Christ is the sacrifice offered for the life of the world. Christ is our Pascha, the pure and perpetual sacrifice offered once and for all (Heb 9, 12). According to the Epistle of Hebrews, Christ as the High Priest offers Himself to God the Father by the Holy Spirit, which is with the participation of the entire Holy Trinity.

The sacrifice of Christ justifies his will and relationship with the Father: "He offers Himself as [a] sacrifice to His Father." Knowing that Christ does not have gnomic will He does experience the human will, but His sacrifice is accomplished by His Father's will, or to say that Father's will becomes His. Bulgakov indicates the inner sacrifice of the Lord, his spiritual experience as 'the will to the cross'. Those inner thoughts are hidden from human reason. It is hardly comprehensible one man's suffering and quite pointless to discuss who God is while he suffers as a man on the cross. Yet, the purpose and meaning of the sacrifice are found only afterwards when it has been accomplished. The Cross and the bodily suffering of Christ is only one aspect of His sacrifice as a whole. The Great Friday is the event when the Lamb willingly died for our sins. It is a day of mourning for the (paradoxically) shameful death of the Lord and also our fatal rejection of Emmanuel. It is a day for reexamination of our faith that we may confess Christ as God who experiences death as a human being. The Crucifixion event is a visible culmination of Christ's suffering and remains the sacrifice after the Great Friday and Resurrection and Ascension. This is one of the reasons why the way to Golgotha and the Passion of Christ is never sentimentally described in the Eastern as much as in the Latin Church. It is hard to express the suffering of a human being whether in words or through images. How hard it is then to describe the inner struggle of Christ who cries out on our behalf: My God, My God why have you forsaken me (Mt 27, 36; Mk 15, 34)?

The eternal and ultimate sacrifice of the Second Person of the Holy Trinity breaks through this world at the same time bringing joy and power of the Kingdom of Heaven. And this Kingdom recognized as with Christ is what matters the most. On the one hand, the high-priest ministry may have its beginning on the Last Supper culminating on the Cross, but the power of its commencement nevertheless speaks of the primordial idea of God which is communion with humanity: "In its preparation, the Lord reveals Himself as the sacrifice and the sacrificing priest at the last Supper, and in the strict sense this is the beginning of His high - priestly ministry, which is already initially present in the Incarnation, as the self-emptying and sacrificial kenosis of Divinity." It is the power of Emmanuel - God with us, that gives meaning not just to His sacrifice, but to the life of faith as well. This is how divine-human reality began as a ground for the latter Eucharistic experience. Therefore, by instituting the sacrificial-redemptive role, Christ actually establishes the eschatological character-His Kingdom which is already here and yet to come:

Whereas Judaism and Islam have one eschatological center, fixed in the future, Christian eschatology unfolds as this tension between two eschatological nodal points: between the already of the incarnation and the not yet of the Parousia. John's eschatology is realized in the revelation of Christ, or better yet inaugurated by the Word's coming to the world. ${ }^{8}$

Bulgakov is aware of the eschatological establishment of the ongoing tension between already and not yet as witnessed in Johannine theology (Jn 4, 23). Accordingly, Eucharistic

6 Bulgakov 2008, 336.

7 Bulgakov 2008. 99.

8 Manoussakis 2007, 29-46. 
theology is Eschatological which is more than prolepsis (i. e. I Cor 11, 26). The Future is made present in the Eucharist and by the Eucharist. ${ }^{9}$ It is why the theology of the Eucharist is that where true theology indeed finds its reference and source. It is in the Eucharist where we have the whole Christ and the Spirit together with humanity before the Father. ${ }^{10}$ Theology of the Eucharist brings one refreshing realm. It is a common experience of entering a conditioned indoor in the midst of a hot summer day. It is hard to get satisfied with a cool breeze which lasts for few seconds or so. It is hard to question or rationalize temporality in this setting. Nevertheless, that very experience of cool air regardless of how long it lasts actually does matter. The taste of that refreshing encounter with Christ in the Eucharist mystically echoes the same experience as the previous example.

This tension between already and not yet is actually the birthplace of Bulgakov's theology. It is right at the center of the ecclesial realm and at the same time defining his whole approach to the source and the reference within the totality of the faith.

We might ask ourselves why do we have different methodologies of the West and East and why has not the Eucharist ceased to be the central act in the East, not just as a visible grace but also as the way of life rather life itself? What is the meaning and purpose of Eucharist for our faith?

The initial distinction and ways of different approaches in the Christian life might be described as two 'experiences' - a distinction between the juridical and the eschatological. The medieval Christian synthesis in the Latin West was based on the 'progressive' departure of the Early Christian notion of the Kingdom of God; elimination not of the term, but of the initial understanding of the Early Church. What was that? It is the antinomical presence in 'this world' of the 'world to come', and the tension which is implied in that antinomy. And here lies the discerning key between two traditions - this antinomy and this tension inherent in the patristic notion of mysterion that the West eliminated from its approach to faith, from its ultimate 'intuition' of God and Divine intention toward creation. If all the old controversies between the Orthodox East and the Latin West - those about Filioque, original sin, created grace, essence and energies, purgatory and even the papacy-controversies which to so many today appear totally irrelevant, were transposed into an 'existential' key, explained in terms of their 'practical' significance, it would become clear that their 'common denominator' in the Eastern mind is, first of all, the rejection by the West of the mysterion - the holding together, in a mystical and existential, rather than rational, synthesis of both the total transcendence of God and His genuine presence. The whole faith and piety of the Church is rooted in that paradox, but not a contradictory experience of - now of that which is to come. It is in a communion of this world with Him who is always 'beyond', where we partake 'the joy and the peace of the Holy Spirit.' Without this paradox we lose 'realized' eschatology understanding it only in its futuristic realization.

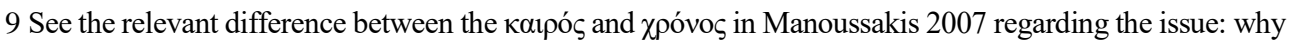
does Church in the Eucharist present feast days of Christ like it was taking place today and this very moment and why does Church know only one temporal category as 'today'?

10 "The hope of participation in a new life is underwritten to believers buy the fact that even now they put on the new man in the power of the Spirit (I Cor 15, 53; Gal 3, 27). It is here that an eschatological turn is given to fellowship with God in that it is interpreted as their final destiny, which is manifested in Jesus Christ and in which believers share through the Spirit, who is already effecting the eschatological reality of the new man in them"; Wong 2008, 31.

11 The Aramaic expression Maranatha witnesses the faith of the Church always in the Eucharistic context (I Cor 16, 20-23 and also in II Cor 13,13) which has three meanings: The Lord has come, The Lord is coming and the Lord will come. 
In order to support the original claim and recognize the high-priestly ministry of Christ in Bulgakov's Sacramental theology as extended in the Eucharist, we must revalue few aspects of the term high-priest expressed in Orthodox iconography. There are two icons under the text which might serve the main theme. The first one is more important for the main argument, namely the fresco of so-called Resurrection (No.1):

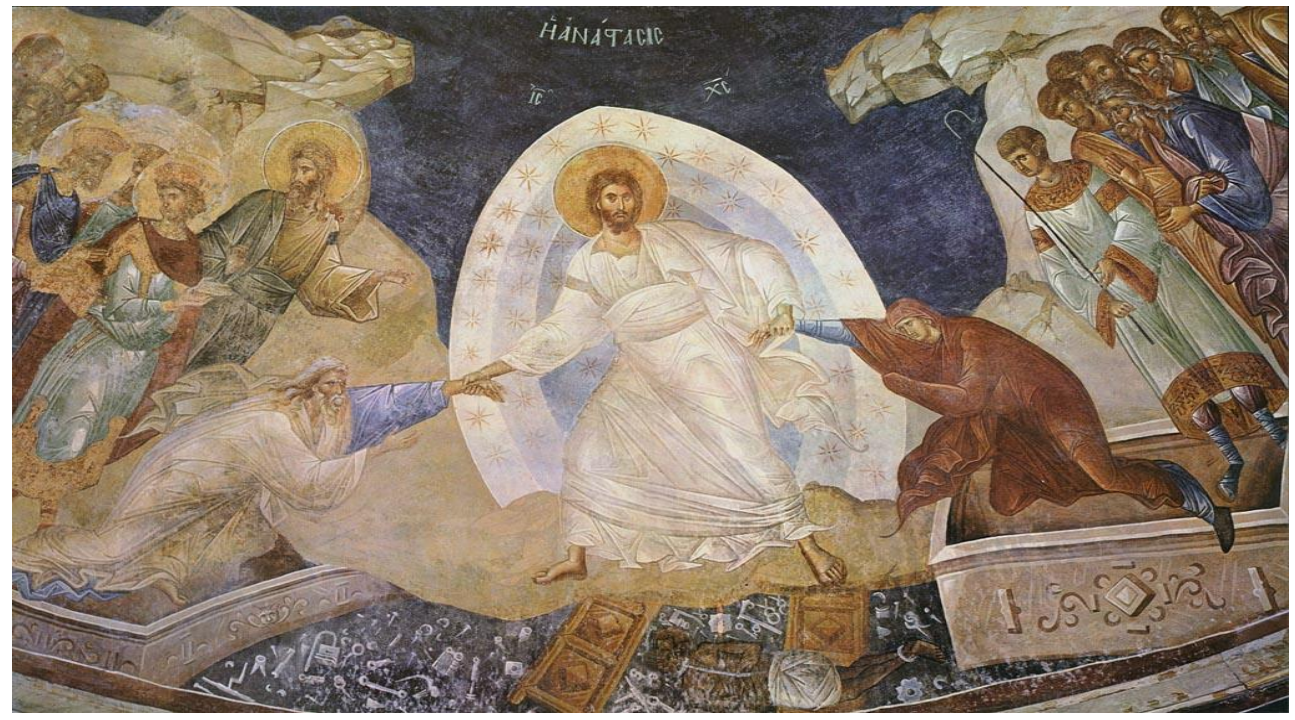

No.1

Even though the proper title is Descent into Hades, ${ }^{12}$ in the Orthodox Church, Christ is rather shown as the Rescuer and the passage for the first humanity to the paradise, e.g. Kingdom of Heaven. In fact, it depicts Christ as the Redeemer and Savior in the first place. In this icon, Christ is the Savior of the world not because of His sacrifice on the Cross and by nullifying the sins of the world. It is primarily because He rose from the dead, trampling down death by death. The problem of the world was not moral - missing the point, transgressing, and even guiltiness, i.g. sons, sont in Latin. The Orthodox emphasis moves from the Great Friday to the new day of Resurrection. The question is ontological since its goal is not just ethical in terms of witnessing a genuine life $(\alpha-\mu \alpha \rho \tau i ́ \alpha)$, but to experience this new life in Christ. It is the question of human existence. That is what Christ brings in this icon and it would not be possible without Divine-

12 One of the most beautiful example of the traditional Byzantine icon of the XIV century comes from the funerary chapel, Monastery of Chora in Istanbul. The All-Powerful Christ, in midst ride lifts the helpless Adam and Eve from their paralyzed mode and state of wonder (sheol) by the wrist like children, this being witnessed by the older King David and younger King Solomon on the left, with St John the Forerunner behind them. On the right, the Protomartyr Abel watches with his shepherd's crook and others of the Old Testament Prophets watch with him. This victory over death, the proclamation to and release of the prisoners (1Pt 3.19), is the purpose for His Resurrection. Resurrection icon presents us with the love of God for mankind, His personal sacrifice, and His personal rescue of humanity from eternal death rather than a history lesson: the tomb, the winding sheet, the Myrrh-Bearing Women, the sleeping guards, the bright-shining angel etc. 
human unity in Resurrected Christ; without the power of God which exists in Christ's body, the light that radiates ${ }^{13}$ and can not die.

This icon shows also and proves Christ as the only one who can actually raise our forefathers. It is worth mentioning that this icon in the East represents a great part in the matrimonial service. The entire scene of the icon is a pedagogical reminder during the wedding ceremony. Christ stands in between Adam and Eve as the one who makes this bridal unity possible. Ultimately, Christ is the one who saves both of them. In fact, Christ completes marriage, because He makes this unity of love everlasting reality and not just the efforts of the married couple on their own.

Christ is celebrating Paschal supper on the Great Thursday, reminding us of the great exodus and salvation of Jews from Egypt. He then continues with the Last Supper which is also a reminder of what Christ has already done for us: His sacrifice and Resurrection. It is the reminder of our salvation. He is our Pascha-Exodus from this world into the Kingdom of Heaven. But, the Eucharist is not just that commemorational act. Christ already offers Himself on the Great Thursday, before betrayal and conviction, even before the crucifixion. Christ shows us His eternal love and the willing sacrifice (Jn 10. 11, 15-18) for the life of the world. So, when Bulgakov speaks of the Passion, he does not use Western terminology of satisfaction. ${ }^{14}$ The whole purpose of the Passion is not the satisfaction of God's wreath. The meaning of Christ's sacrifice on the Cross is unconditional love which is priceless. If the sacrifice was to be paid, it is already the degradation of the sacrifice. That is why Christ' death on the cross is the act of eternal love and eternal sacrifice which was done once for all and forever.

Christ has shown His love through the cross, the instrument of His victory over death. It was the way of Cross that His love was manifested, but through His Resurrection, we ultimately attain His love as the way of our salvation. The 'Bodily agony' of Christ thus has started with the Incarnation and continued on the Great Thursday. The sacrifice on the Cross concludes Christ's earthly sacrifice in his body, which is by the Holy Spirit extended in the Eucharist. The Eucharist thus remains the mystagogical act to remind us of what Christ has done for us, and at the same time to give us Christ. This is an eschatological event, the breakthrough of the Kingdom of God into this world: the new world given to us, where Christ is present and real.

Concluding thoughts of Bulgakov's high priestly theology refresh us with the rather fourth dimension of the Kingdom of God. Christ's ministry is "manifested as Eucharistic power, the mysterious connection of the glorified Christ with the man in communion and the unceasing sanctification of the elements of the world through the presence in them of the Sacred Gifts, the Body and the Blood of Christ". ${ }^{15}$ The peace and joy of the Kingdom is what Emanuel brings us in His sacrifice through His whole earthly live. God is with us - not just historically or commemoratively, neither as His sacrifice on the Cross. His bodily suffering trans-subjectively lives in the Eucharist for the life of all. It is the emphasis on the joy of humanity becoming new, humanity co-resurrecting with Christ and partaking of Him in eternity, already here and now.

13 The Resurrection of Christ is the proof that He is one of the Trinity and that our faith is not in vain. More on this Bulgakov stresses in one section on the Transfiguration as a revelation of Christ Divinity which affects present reality. When Eschatological reality is shown it presents realm beyond time. Therefore we have Elijah and Moses standing next to Christ, etc.

14 This is part of the scholastic theory of Anselm of Canterbury that of Christ has come that He may redeem or satisfy insulted God's righteousness. What is the most important thing here is salvation of humanity, the birth, re-birth of fallen man. Christ 'establishes' vivified humanity, He makes humanity new. Christ offers humanity the gift of everlasting life.

15 Bulgakov 2008, 436. 


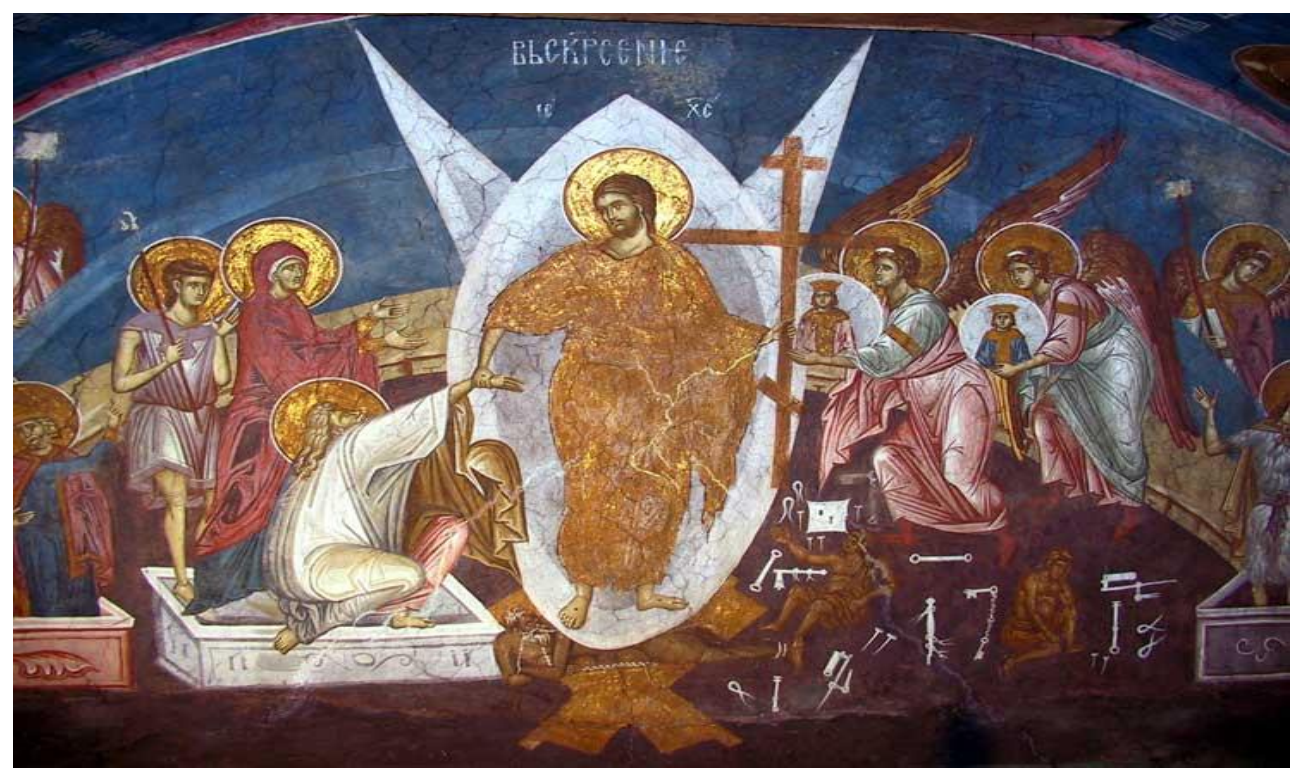

No.2

A description of the icon No.2:

Visoki Dečani Monastery, the first cultural monument on the territory of Serbia to be inscribed in the list of UNESCO World Heritage has long been known as one of the architecturally most interesting and best-preserved Serbian medieval churches in which traditions of Romanesque architecture meet artistic patterns of the Byzantine world. If we look at the XIV century fresco, we will find the great connection of Christ who tramples death by death, e.g. the Cross in His left hand, and who liberates rather than raises Adam and Eve from the bondage of Sheol. Christ is the prototype of the first uncorrupted body. Pauline's theology illuminates the sadness of the great Friday (I Cor 15, 14). It is the bright sadness experienced in the Church where we reap the same and the most blessed fruit of His Resurrection.

\section{Bibliography}

Bulgakov, Sergius (2008): The Lamb of God. Grand Rapids-Michigan/ CambridgeUK: Eerdmans.

Irenaeus (2004): Adversus Heresies. book I, ANF, Peabody-MA: Hendrickson Publishers.

Manoussakis, John Panteleimon (2007): The anarchic principle of Christian Eschatology in the Eucharistic Tradition of the Eastern Church: Harvard Theological Review 100, no. 1 (2007): 29-46.

Russell, Norman (2004): The Doctrine of Deification in the Greek Patristic Tradition. Oxford University Press.

Theologian, Gregory (2004): On the Baptism of Jesus. book VII, NPNF, PeabodyMA: Hendrickson Publishers.

Wong, Kam Ming (2008): Wolfhart Pannenberg on Human Destiny, EnglandAshgate Publishing. 


\section{Ђорђе Н. Петровић}

\section{ХРИСТОВА ПРВОСВЕШТЕНИЧКА СЛУЖБА: УВОД У СВЕТОТАЈИНСКО БОГОСЛОВЉЕ СЕРГЕЈА БУЛГАКОВА}

Христова првосвештеничка служба је једна од тема коју је Булгаков обрадио нарочито у делу Јагње Божије. Наслов предлаже главну тему, Христова првосвештеничка служба као увод у богословље Булгакова, из два разлога. Први разлог: Христова првосвештеничка служба остварена је на Крсту и кроз Васкрсење. Други разлог: Христова служба се наставља односно продужава у Евхаристији. Поред неких теологумена које можда сврставају Булгакова као православног мислиоца или философа пре него једног богослова, тема првосвештеничка служба отвара срж његовог разумевања Христологије и Светотајинског богословља. Задатак рада је да препознамо Христову првосвештеничку службу у светотајинском богословљу Булгакова настављену у Евхаристији. Циљ је да изнова проценимо неколико гледишта термина првосвештеничка служба и значај за богословње уопште. 